\title{
Do clinical and laboratory parameters effect maternal and fetal outcomes in pregnancies complicated with hemolysis, elevated liver enzymes, and low platelet count syndrome?
}

\author{
Klinik ve laboratuvar özellikler hemoliz, artmıs karaciğer enzimleri ve düsük \\ trombosit sayımı sendromlu gebelerde maternal ve fetal sonuçları etkiler mi?
}

\author{
İncim Bezircioğlu, Ali Baloğlu, Burcu Çetinkaya, Betül Pirim \\ Department of 1st Gynecology and Obstetrics, Izmir Atatürk Training and Research Hospital, Izmir, Turkey
}

\section{Abstract}

Objective: The aim of the study was to investigate whether the clinical features and laboratory parameters affect maternal and fetal outcomes in pregnancies complicated with HELLP syndrome.

Material and Methods: The medical records of pregnant patients complicated with HELLP syndrome were analyzed retrospectively between June 01, 2003 and June 01, 2010. The demographic data, medical history, admission symptoms, clinical and laboratory findings and recovery time were evaluated. The adverse maternal outcomes including eclampsia, placental abruption, disseminated intravascular coagulation, postpartum hemorrhage, pulmonary complications, cerebral edema and visual loss were recorded. Fetal growth restriction, necessity for neonatal intensive care unit admission and perinatal mortality were recorded as an adverse fetal outcome.

Results: The incidence of HELLP syndrome was $0.52 \%$. The mean age of the patients was $28.93 \pm 7.90$ (range 17-45). HELLP syndrome was diagnosed on average in the $33.68 \pm 4.41^{\text {th }}$ (ranged 24-40) week of gestation. Eighteen cases (40.9\%) were nullipara and twenty-six cases (59.1\%) multipara. The most common complications were eclampsia (40.9\%) and abruption placenta (15.9\%). Pregnancy was terminated within 48 hours in all patients. The rate of cesarean section was $90.9 \%$. Perinatal mortality rate in HELLP syndrome was $31.8 \%$. There was no maternal mortality.

Conclusion: Neither clinical characteristics nor laboratory parameters was found effective for prediction of adverse maternal and fetal outcomes. (J Turkish-German Gynecol Assoc 2012; 13: 1-7)

Key words: HELLP syndrome, preeclampsia, maternal outcome, fetal outcome

Received: 22 June, 2011

Accepted: 28 September, 2011

\section{Özet}

Amaç: Çalışmanın amacı HELLP sendromlu gebelerde klinik özellikler ile laboratuvar belirteçlerinin maternal ve fetal sonuçları etkileyip etkilemediğini araştırmaktır.

Gereç ve Yöntemler: 01 Haziran 2003 ile 01 Haziran 2010 tarihleri arasında HELLP sendromlu gebe kadınların tıbbi kayıtları geriye dönük olarak incelendi. Demografik verileri, tıbbi öyküsü, başvuru yakınmaları, klinik ve laboratuvar bulguları ve iyileşme süreleri değerlendirildi. Eklampsi, plasenta dekolmanı, yaygın damar içi pıhtılaşma, postpartum kanama, akciğer komplikasyonları, beyin ödemi ve görme kaybını içeren olumsuz maternal sonuçlar kaydedildi. Fetal büyüme kısıtlılığı, yenidoğanın yoğun bakıma kabulü, perinatal mortalite olumsuz fetal sonuçlar olarak kaydedildi.

Bulgular: HELLP sendromu insidansı $\% 0.52$, olguların ortalama yaşı $28.93 \pm 7.90$ (aralık 17-45) idi. HELLP sendromu gebeliğin ortalama $33.68 \pm 4.41$ (aralık 24-40) haftasında tanındı. 18 olgu nullipar (\%40.9), 26 olgu (\%59.1) multipar idi. En sık komplikasyon eklampsi (\%40.9) ve ablasyo plasenta (\%15.9) oldu. Tüm hastalarda gebelik 48 saat içerisinde sonlandırıldı. Sezaryen hızı \%90.9, perinatal mortalite \%31.8 idi. Hiç maternal mortalite görülmedi.

Sonuç: Ne klinik özellikler ne de laboratuvar belirteçler olumsuz maternal ve perinatal sonuçlanı öngörmede etkili bulunmadı.

(J Turkish-German Gynecol Assoc 2012; 13: 1-7)

Anahtar kelimeler: HELLP sendromu, preeklampsi, maternal sonuç, fetal sonuç

Geliş Tarihi: 22 Haziran 2011

Kabul Tarihi: 28 Eylül 2011

\section{Introduction}

Hemolysis, elevated liver enzymes, and low platelet count (HELLP) syndrome is regarded as a variant or complication of preeclampsia. The HELLP syndrome occurs in 0.5 to $0.9 \%$ of all pregnancies and in 10 to $20 \%$ of cases with severe preeclampsia (1). In the Tennessee Classification System diagnostic criteria, the presence of hemolysis ( $\mathrm{LDH}>600 \mathrm{U} / \mathrm{L}$ ), elevated liver enzymes (AST >70U/L) and thrombocytopenia $\left(<100.000 / \mathrm{mm}^{3}\right)$ were accepted as HELLP syndrome. The patients who met two of three criteria were accepted as partial HELLP syndrome (2).

Patients whose pregnancies are complicated by HELLP syndrome are at high risk for complications such as abruption

Address for Correspondence: Incim Bezircioğlu, 1420 Sok. No: 110/5 Alsancak 35220 İmir, Turkey

Phone: +902327547182 e.mail: drincimbezircioglu@yahoo.com

(C) Copyright 2012 by the Turkish-German Gynecological Education and Research Foundation - Available online at www.jtgga.org doi:10.5152/jtgga.2011.68 
placenta, disseminated intravascular coagulation, acute renal failure, adult respiratory distress syndrome, and multiple organ dysfunction syndrome $(1,2)$. The HELLP syndrome is associated with increased risk of adverse fetal outcome because of intrauterine growth restriction, and prematurity (2). Clinical characteristics and laboratory data could not provide prediction of clinical course and adverse outcomes (3).

In the present study, we analyzed the pregnancies complicated by HELLP syndrome and the effects of maternal clinical features and laboratory parameters on adverse maternal and fetal outcomes were investigated.

\section{Material and Methods}

The pregnancies complicated with HELLP syndrome who were delivered in the Department of Obstetrics and Gynecology, İzmir Atatürk Training and Research Hospital, Turkey from June 01, 2003 to June 01, 2010 were evaluated retrospectively. We recruited all the patients with HELLP syndrome in the study period. The presence of hemolysis $(\mathrm{LDH}>600 \mathrm{U} / \mathrm{L})$, elevated liver enzymes (AST $>70 \mathrm{U} / \mathrm{L})$ and thrombocytopenia $(<100.000 /$ $\mathrm{mm}^{3}$ ) were accepted as HELLP syndrome. We recorded the patients who had two of three criteria were as partial HELLP syndrome. The exclusion criteria were hypertension and proteinuria before the $20^{\text {th }}$ gestational week and other medical conditions including renal, hepatic, hematologic and cardiovascular diseases.

The demographic and clinical data including maternal age, parity, past history of preeclampsia, and hypertension, presenting symptoms, clinical findings and gestational age at admission, systolic and diastolic blood pressures at its maximum during the management, duration of hospital stay were recorded for all patients. The results of liver function tests, complete blood cell counts, coagulation profile, and renal function tests were collected. The adverse maternal outcomes including eclampsia, abruption placenta, disseminated intravascular coagulation, postpartum hemorrhage, pulmonary edema, cerebral edema, visual loss and adverse fetal outcome including fetal growth restriction, neonatal intensive care admission and perinatal mortality were recorded.

Eclampsia is defined as tonic-clonic seizures occurring in a hypertensive pregnancy, with or without proteinuria. Postpartum hemorrhage is defined as blood loss greater than $500 \mathrm{~mL}$ during a vaginal delivery or greater than $1,000 \mathrm{~mL}$ with a cesarean delivery. Pulmonary edema was diagnosed based on clinical findings and chest radiograph. Cerebral edema was diagnosed based on neurologic complaints with clinical findings, and Magnetic Resonance Imaging. Disseminated intravascular coagulation was defined as the presence of three or more of the following criteria: low platelets $(<100.000$ per $\mu \mathrm{l})$, low fibrinogen $(<300$ $\mathrm{mg} / \mathrm{dl}$ ), or prolonged prothrombin (>14 seconds) time.

Fetal growth restriction was defined as birth weight less than the fifth percentile. Fetal mortality was defined as intrauterine death of a fetus at any time during pregnancy. Perinatal mortality was defined as fetal death plus neonatal death within the first 7 days. Gestational age was determined according to the last menstrual period or first trimester ultrasonographic biom- etry. All patients received magnesium sulfate (Magnezyum sulfat $15 \%$ in $10 \mathrm{ml}$, Biofarma, Istanbul, Turkey) as a $4.5 \mathrm{~g}$ intravenous loading dose followed by a $2 \mathrm{~g}$ maintenance dose per hour. Continuous infusion of glycerol trinitrate (Perlinganit, $10 \mathrm{mg}$, Adeka, Samsun, Turkey) was administered to control severe hypertension. An aggressive management protocol was decided on. All cases over 34 weeks of gestation were delivered promptly. Pregnancies before 34 weeks of gestation were terminated within 48 hours following corticosteroid therapy. 12 mg betamethasone (Celestone amp, $3 \mathrm{mg}$, Eczacıbası, Istanbul, Turkey) was administered intramuscularly twice at a 24 hour interval. Induction of labor and delivery route were recorded. Apgar score, birth weight, requirement for neonatal intensive care unit and neonatal outcomes were evaluated. Developing complications were recorded.

Statistical analysis was carried out using SPSS 11.0 for Windows (SPSS Inc, Chicago, III, USA) statistical software. Categorical variables were described using frequency distribution and compared by Chi-square and Fisher's exact test. For continuous variables, descriptive statistics were calculated and reported as mean \pm standard deviation. Student-t test was used to compare mean scores of continued variables between two groups. $\mathrm{p}<0.05$ was accepted as the level of significance.

\section{Results}

Between June 01, 2003 and June 01, 2010, of 8384 deliveries 44 cases were found to be complicated with HELLP syndrome. In this period, 232 deliveries were complicated with preeclampsia. The incidence of HELLP syndrome was 0.52 percent in our department. While 37 patients met the complete criteria for HELLP syndrome, 7 patients were classified as partial HELLP syndrome. Eighteen cases (40.9\%) were nullipara and twentysix cases (59.1\%) multipara. The most common presenting clin-

Table 1. Histories and clinical features of HELLP syndrome cases

\begin{tabular}{|c|c|c|}
\hline & Number & Percent \\
\hline \multicolumn{3}{|l|}{ History } \\
\hline Multiply pregnancy & 2 & 4.5 \\
\hline Assisted Reproductive technology & 2 & 4.5 \\
\hline Diabetes & 2 & 4.5 \\
\hline Previous cesarean & 4 & 9.1 \\
\hline \multicolumn{3}{|l|}{ Symptoms at presentation } \\
\hline Headache & 2 & 4.5 \\
\hline Edema & 9 & 20.5 \\
\hline Epigastric discomfort & 7 & 15.9 \\
\hline Nausea-vomiting & 3 & 6.8 \\
\hline Hypertension & 15 & 34.1 \\
\hline Convulsion & 3 & 6.8 \\
\hline Confusion & 1 & 2.3 \\
\hline Labor & 4 & 9.1 \\
\hline
\end{tabular}


ical feature was that the patient was referred for hypertension. Historical and clinical features of HELLP syndrome patients were showed in Table 1.

Five of the patients had arterial systolic blood pressures $>160$ $\mathrm{mmHg}$ or diastolic blood pressures $>110 \mathrm{mmHg}$ which are the criteria for severe preeclampsia. The platelet count was below $50,000 \mathrm{~mm}^{3}$ in 12 patients, between 50,000 and 100,000 $\mathrm{mm}^{3}$ in 28 patients, and between 100,000 and $150,000 \mathrm{~mm}^{3}$ in four patients. Proteinuria was below $300 \mathrm{mg} / 24$ hours in nine patients (20.5\%), and over $5 \mathrm{~g}$ in one patient. Clinical and laboratory characteristics of the patients with HELLP syndrome were presented in Table 2.

Fetal growth restriction was determined in 16 patients. The presence of growth restricted fetuses did not predict either maternal $(p=0.325)$ or fetal $(p=0.864)$ adverse outcomes.

Gestational age at diagnosis among patients whose babies were growth retarded was significantly higher than that among patients without this complication ( $35.6 \pm 2.7$ vs $32.6 \pm 4.8$ weeks' gestation; $\mathrm{p}=0.03$ ).
Preventive corticosteroid therapy was administered in 18 pregnancies before 34 weeks of gestation and all of them were terminated within 48 hours.

In forty cases, the pregnancies were terminated by cesarean section within 48 hours after diagnosing HELLP syndrome. General anesthesia was selected and performed for all cesarean sections. Indications for cesarean section included fetal distress, previous cesarean section, failed induction of labor, unfavorable cervix and persistent high arterial blood pressure (above 160/110 mmHg). The rate of cesarean section was $90.9 \%$ in this series.

Seven of the cases developed placental detachment and three of them had intrauterine fetal demise. Postpartum hemorrhage developed in four patients. While three of them could be managed by medical treatment, hysterectomy was performed in one patient. Acute renal failure, sepsis, or maternal death did not occur in the present series.

Twenty of the 41 live-born babies needed neonatal intensive care. In fifteen of them, birth weights were below 1500 g. Early

Table 2. Clinical and laboratory characteristics of HELLP syndrome cases

\begin{tabular}{|c|c|c|c|}
\hline HELLP Syndrome (n:44) & Mean & Standard deviation & Range History \\
\hline Maternal age (years) & 28.93 & 7.90 & $17-45$ \\
\hline Parity & 1.60 & 1.51 & $0-5$ \\
\hline Gestational weeks & 33.68 & 4.41 & $24-40$ \\
\hline Systolic blood pressure (mm Hg) & 172.78 & 27.18 & $130-230$ \\
\hline Diastolic blood pressure (mm Hg) & 107.22 & 9.58 & $90-130$ \\
\hline Alanine aminotransferase (U/L) & 314.44 & 294.42 & $41-991$ \\
\hline Aspartate aminotransferase (U/L) & 466.94 & 374.02 & 69-1329 \\
\hline Lactic dehydrogenase (U/L) & 2644 & 1852 & $600-9132$ \\
\hline Total bilirubin (mg/dL) & 2.01 & 3.21 & $0.20-13.60$ \\
\hline Direct bilirubin (mg/dL) & 1.05 & 1.76 & $0.05-7.53$ \\
\hline Urea (mg/dL) & 17.29 & 5.20 & $6-28$ \\
\hline Creatinine (mg/dL) & 0.86 & 0.22 & $0.50-1.41$ \\
\hline Hemoglobin $(\mathrm{g} / \mathrm{dL})(\%)$ & 12.02 & 1.50 & $8.73-14.60$ \\
\hline Hematocrit (g/dL) (\%) & 35.78 & 4.77 & $25-42$ \\
\hline Platelet count $\left(\mathrm{X} 10^{9} \mathrm{~L}\right)$ & 68584.09 & 32810.57 & $29000-168000$ \\
\hline Fibrinogen level (mg/dL) & 328.81 & 139.64 & $129-534$ \\
\hline Prothrombin time (sn) & 11.44 & 2.11 & $9.10-16.30$ \\
\hline INR (sn) & 0.96 & 0.17 & $0.75-1.34$ \\
\hline Fetal weight (grams) & 2071.82 & 800.24 & $570-3180$ \\
\hline Apgar score & 7.36 & 2.01 & $3-10$ \\
\hline Blood pressure recovery time (day) & 3.65 & 2.49 & $1-9$ \\
\hline ALT recovery time (day) & 3.0 & 1.71 & $1-7$ \\
\hline LDH recovery time (day) & 2.95 & 1.67 & $1-7$ \\
\hline Platelet count recovery time (day) & 2.80 & 1.9 & $1-5$ \\
\hline Postpartum stay in hospital (day) & 7.66 & 3.29 & $4-21$ \\
\hline
\end{tabular}


neonatal death occurred in eleven infants during the first seven days of postnatal period. In all of the pregnancies complicated with perinatal mortality, birth weights were below $1500 \mathrm{~g}$. The main indications for neonatal intensive care admission of twenty cases were respiratory distress syndrome due to prematurity. Mean gestational age was significantly lower in patients with adverse fetal outcomes than those without these complications ( $30.7 \pm 3.5$ vs $37.2 \pm 2.3$ weeks; $\mathrm{p}<0.001)$.

Arterial systolic blood pressure among the patients with adverse fetal outcome was significantly higher than among the patients without adverse fetal outcome $(175.0 \pm 23.0$ vs $163.2 \pm 12.8$ mmHg; $p=0.048$ ). Similarly, diastolic blood pressure among the patients with adverse fetal outcome was significantly higher than among the patients without adverse fetal outcome (109.8 \pm 8.8 vs $101 . \pm 9.6 \mathrm{mmHg} ; \mathrm{p}=0.005)$. There was no association between adverse maternal outcome and nadir platelet counts $<50000$ cells $/ \mathrm{mm}^{3}$. The patients with intrauterine growth retarded fetuses had significantly lower platelet counts than patients without intrauterine growth retarded fetuses (247173.3 \pm 142503.4 cells $/ \mathrm{mm}^{3}$ vs $134240.0 \pm 52930.0$ cells $/ \mathrm{mm}^{3}$; $\mathrm{p}=0.019$ ). There was no association between perinatal morbidity and low platelet count.

There was no difference in recovery time of the arterial blood pressure, platelet count, serum alanine aminotransferase, and lactic dehydrogenase levels between the patients treated with and without corticosteroid therapy for rescue surfactant. Recovery time for alanine aminotransferase was significantly longer in patients who developed eclampsia than patients did not $(4.4 \pm 1.4 \mathrm{U} / \mathrm{L}$ vs $2.2 \pm 1.4 \mathrm{U} / \mathrm{L} ; \mathrm{p}=0.003)$. There was no significant association between recovery time for other laboratory parameters or blood pressure and adverse outcomes. In Table 3, it can be seen that complications were caused by HELLP syndrome.

Table 3. The complications of patients with HELLP syndrome

\begin{tabular}{|l|c|c|}
\hline Complication & Number & Percent \\
\hline Hematuria & 16 & 36.4 \\
\hline Visual loss & 5 & 11.4 \\
\hline Pulmonary edema & 4 & 9.1 \\
\hline Cerebral edema & 5 & 11.4 \\
\hline Eclampsia & 18 & 40.9 \\
\hline Abruption placenta & 7 & 15.9 \\
\hline $\begin{array}{l}\text { Disseminated intravascular } \\
\text { coagulation }\end{array}$ & 1 & 2.3 \\
\hline Postpartum hemorrhage & 3 & 6.8 \\
\hline Hysterectomy & 1 & 2.3 \\
\hline Induction of labor & 3 & 6.8 \\
\hline Cesarean section & 40 & 90.9 \\
\hline Fetal growth restriction & 16 & 36.4 \\
\hline Neonatal intensive care & 20 & 45.5 \\
\hline Fetal mortality & 3 & 6.8 \\
\hline Perinatal mortality & 14 & 31.8 \\
\hline
\end{tabular}

The clinical and laboratory data were studied for the relation with each adverse outcome variables, then for the relation with the presence of at least one of the outcome variables. The results were summarized in the Tables 4 and 5 . Because the results were not found significant for prediction of adverse maternal and fetal outcomes, so that correlation analysis was not performed.

\section{Discussion}

We presented the findings of our complete and partial HELLP syndrome series. Our rate of HELLP syndrome was in $0.52 \%$ of deliveries and $18.96 \%$ of severe preeclampsia, consistent with the previously reported values $(4,5)$.

The peak frequency of the HELLP syndrome was between the $27^{\text {th }}$ and $37^{\text {th }}$ gestational weeks; $10 \%$ occured before the $27^{\text {th }}$ week, and $20 \%$ beyond the $37^{\text {th }}$ gestational week. Most women with HELLP syndrome were multiparous $(1,4)$. We found that mean gestational age was 33 weeks, $11 \%$ occurred before the $27^{\text {th }}$ weeks, $18 \%$ after the $37^{\text {th }}$ gestational week. $59.1 \%$ of our series were multiparous. In about $70 \%$ of cases, the HELLP syndrome developed between the $27^{\text {th }}$ and $37^{\text {th }}$ gestational weeks. Hypertension and proteinuria were the most common symptom at presentation in the majority of patients with the HELLP syndrome, which may be absent in $10-20 \%$ of the cases. Up to $30-60 \%$ of women have headache and about $20 \%$ visual symptoms (2). Excessive weight gain and generalized edema precede the syndrome in over $50 \%$ of the cases (1). Hypertension was the reason for referral in $34 \%$ of cases, but it was found that all of the cases had hypertension, proteinuria and edema. At presentation, headache was present in $4.5 \%$ and visual symptoms in $11 \%$ of cases.

The HELLP syndrome is associated with serious maternal and fetal complications $(2,5,6)$. It is not yet established whether expectant management in preterm pregnancies with HELLP syndrome would improve perinatal outcome or not. Therefore prompt delivery is recommended if the HELLP syndrome occurs after the $34^{\text {th }}$ week or the fetal and/or maternal conditions deteriorate. Abruption placenta, acute renal failure, DIC and subsequent postpartum bleeding were reported as common maternal complications (1). Abruption placenta was strongly correlated with the development of disseminated intravascular coagulation. Our rate of abruption placenta was consistent with respect to other studies (3, 5, 7-9). However, disseminated intravascular coagulation was encountered at a relatively lower rate than in other series $(3,7,9,10)$. Postpartum hemorrhage developed in four patients who had placental detachment, which was consistent with respect to other studies (11). Acute renal failure is encountered between 5 and 36 percent in patients with HELLP syndrome $(3,5,7,10,12,13)$. The patients with postpartum HELLP syndrome have significantly higher incidences of pulmonary edema and renal failure (3). In the present study, even if some of the patients had temporary oliguria, none of them developed acute renal failure. Furthermore, the HELLP syndrome occurred in none of them during the postpartum period. The absence of acute renal failure and maternal mortality may be relevant to this condition. 
Eclampsia was reported between 5 and 52 percent in previous series $(5,7,9,11)$. We encountered much more eclampsia in our series than previously reported. We preferred to perform a cesarean section in patients complicated with eclampsia. Therefore our rate of cesarean delivery was higher than in previously reported studies.

Haddad et al. (7) found that women with nadir platelet counts $<50000$ cells $/ \mathrm{mm}^{3}$ had increased risk for adverse maternal outcomes when compared with nadir platelet counts between 50000 and 10000 cells $/ \mathrm{mm}^{3}$. They revealed that the incidence of disseminated intravascular coagulation increased among women with nadir platelet counts $<50000$ cells $/ \mathrm{mm}^{3}$. However, the risk did not increase for eclampsia, abruption placenta or other maternal adverse outcomes. Laboratory parameters such as LDH, ALT, bilirubin serum concentration had not been found associated with any adverse maternal outcomes. Ertan et al. found that patients with low platelet counts $(<60,000$ cells/ $\mathrm{mm}^{3}$ ) had a higher incidence of intrauterine growth retarded fetuses than patients with higher platelet counts (13). On the other hand, Cavkaytar et al. (11) suggested that clinical symptoms such as headache, visual changes, epigastric pain and nausea-vomiting were better predictors of adverse maternal outcome than laboratory parameters. In this study, eclampsia, placental abruption and other maternal adverse outcome were not associated with clinical symptoms such as arterial blood pressure, or the other laboratory parameters. The patients with intrauterine growth retarded fetuses had significantly lower platelet counts than patients without intrauterine growth retarded fetuses in our series. However, there was no association between perinatal morbidity and low platelet count.

Perinatal mortality rate related to the HELLP syndrome is between 8 and 40 percent $(1,6,8-10,12,13)$. Most of the perinatal deaths were associated with abruption placenta, intrauterine asphyxia and extreme prematurity (8). In the present study,

Table 4. The association between the clinical symptoms and maternal and fetal adverse outcomes.

\begin{tabular}{|c|c|c|c|c|c|}
\hline & \multicolumn{4}{|c|}{ Adverse maternal outcome } & \multirow{3}{*}{ p value } \\
\hline & \multicolumn{2}{|c|}{ present } & \multicolumn{2}{|c|}{ absent } & \\
\hline & Number & Percent & Number & Percent & \\
\hline Multiple pregnancy & 3 & 12.5 & 23 & 88.5 & $0.258 *$ \\
\hline $\begin{array}{l}\text { Pregnancies after assisted } \\
\text { reproduction treatment }\end{array}$ & 2 & 7.7 & 24 & 92.3 & $0.505^{*}$ \\
\hline Diabetes mellitus & 1 & 3.8 & 25 & 96.2 & $1.00 *$ \\
\hline Headache & 1 & 3.8 & 25 & 96.2 & $1.00 *$ \\
\hline Edema & 5 & 19.2 & 21 & 80.8 & 0.809 \\
\hline Epigastric discomfort & 4 & 15.4 & 22 & 84.6 & $1.00 *$ \\
\hline Vomiting & 1 & 3.8 & 25 & 96.2 & $0.558^{*}$ \\
\hline Convulsion & 3 & 11.5 & 23 & 88.5 & $0.258 *$ \\
\hline Confusion & 0 & 0 & 26 & 100 & $0.409 *$ \\
\hline Hypertension & 8 & 30.8 & 18 & 69.2 & 0.576 \\
\hline Labor & 3 & 11.5 & 23 & 88.5 & $0.258^{*}$ \\
\hline \multicolumn{5}{|c|}{ Adverse fetal outcome } & \\
\hline Multiple pregnancy & 3 & 12.5 & 21 & 87.5 & $0.239 *$ \\
\hline $\begin{array}{l}\text { Pregnancies after assisted } \\
\text { reproduction treatment }\end{array}$ & 2 & 8.3 & 22 & 91.7 & $0.493^{*}$ \\
\hline Diabetes mellitus & 0 & 0 & 24 & 100 & $0.455^{*}$ \\
\hline Headache & 1 & 4.2 & 23 & 95.8 & $1.00 *$ \\
\hline Edema & 3 & 12.5 & 21 & 87.5 & $0.261 *$ \\
\hline Epigastric discomfort & 4 & 16.7 & 20 & 80.3 & $1.00 *$ \\
\hline Vomiting & 1 & 4.2 & 23 & 95.8 & $0.583^{*}$ \\
\hline Convulsion & 1 & 4.2 & 23 & 95.8 & $0.583^{*}$ \\
\hline Confusion & 1 & 4.2 & 23 & 95.8 & $1.00 *$ \\
\hline Hypertension & 9 & 37.5 & 15 & 62.5 & 0.601 \\
\hline Labor & 3 & 12.5 & 21 & 87.5 & $0.614^{*}$ \\
\hline
\end{tabular}


Table 5. The association between the maternal clinical features and laboratory parameters and adverse maternal and fetal outcomes

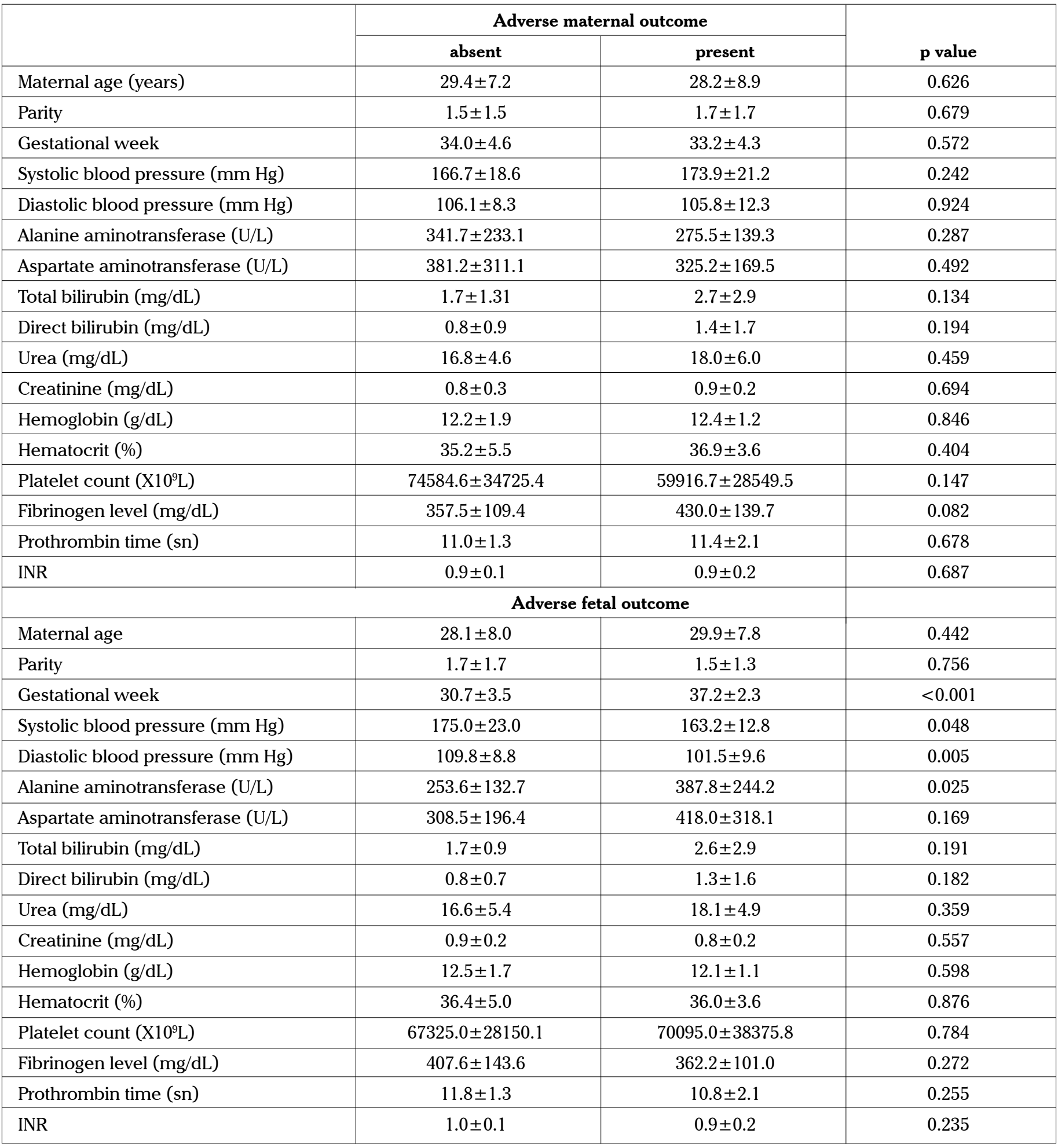

the rate of perinatal mortality was $31 \%$. The main reasons of neonatal mortality were the complications attributed to prematurity. Also information about about neonatal long term survey was not possible due to the retrospective nature of the study. Maternal mortality rate is $1.1-9.0 \%$ in pregnancies complicated with the HELLP syndrome $(3,6,10,12,13)$. Although the most reported cause of death is cerebral hemorrhage, it was stated that multiple organ failure, disseminated intravascular coagulation and adult respiratory distress are contributing pathologies (1). Aggressive management of HELLP syndrome with expeditious 
delivery prevented development of adult respiratory distress syndrome, acute renal failure, and maternal mortality in the present series, and also yielded higher perinatal mortality due to prematurity than previously reported series (14).

In their retrospective study, Meccacci et al. (15) stated that the use of dexamethasone in patients with HELLP syndrome was associated with faster regression and lower incidence of complications in comparison to heparin. In the current cohort, betamethasone, not dexamethasone, was used; no association was found between corticosteroid therapy and recovery time or maternal complications. Recovery time was longer in patients who developed eclampsia than patients without this complication.

Postpartum hospital stay is shorter than 6 days in 63\% of Vigil-De Gracia's series and longer than eleven days in $8 \%$ of them (5). In the present cohort, 29 percent of the patients stayed in hospital shorter than 6 days and 13.6 percent of the patients longer than eleven days.

In the present study, we investigated the effect of clinical features and laboratory parameters related to HELLP syndrome. The patients in earlier weeks of gestation had higher arterial blood pressure, higher serum alanine aminotransferase levels, and consequently a more severe clinical picture. The development of the HELLP syndrome in early gestational weeks increased adverse fetal outcomes. However, no other association was found between clinical or laboratory features and adverse outcomes. Prompt intervention could have prevented maternal mortality. In view of the increased risk of morbidity and mortality, delivery is considered the ultimate therapeutic approach for the HELLP syndrome.

\section{Conflict of interest}

No conflict of interest was declared by the authors.

\section{References}

1. Haram K, Svendsen E, Abildgaard U. The HELLP syndrome: Clinical issues and management. A review. BMC Pregnancy and Childbirth 2009; 9: 8. [CrossRef]

2. Sibai BM. Diagnosis, controversies, and management of the syndrome of hemolysis, elevated liver enzymes, and low platelet count. Obstet Gynecol 2004; 103: 981-91. [CrossRef]
3. Celik C, Gezginc K, Altintepe L, Tonbul Z, Yaman ST, Akyurek C, et al. Results of the pregnancies with HELLP syndrome. Ren Fail 2003; 25: 613-8. [CrossRef]

4. Guzel AI, Kuyumcuoglu U, Celik Y. Are maternal and fetal parameters related to perinatal mortality in HELLP syndrome? Arch Gynecol Obstet 2011; 283: 1227-32. [CrossRef]

5. Vigil-De Gracia P. Pregnancy complicated by pre-eclampsiaeclampsia with HELLP syndrome. Int J Gyneacol Obstet 2001; 72: 17-23. [CrossRef]

6. Sibai BM, Ramadan MK, Usta I, Salama M, Mercer BM, Friedman SA. Maternal morbidity and mortality in 442 pregnancies with hemolysis elevated liver enzymes, and low platelets (HELLP syndrome). Am J Obstet Gynecol 1993; 169: 1000-6.

7. Haddad B, Barton JR, Livingston JC, Chahine R, Sibai BM. Risk factors for adverse maternal outcomes among women with HELLP (hemolysis, elevated liver enzymes, and low platelet count) syndrome. Am J Obstet Gynecol 2000; 183: 444-8. [CrossRef]

8. Yucesoy G, Cakiroglu Y, Bodur H, Ozkan S, Tan T. An analysis of HELLP syndrome cases: does platelet count predict adverse maternal and fetal outcomes in women with HELLP syndrome? Arch Gynecol Obstet 2011; 283: 941-5. [CrossRef]

9. Chhabra S, Qureshi A, Datta N. Perinatal outcome with HELLP/ partial HELLP complicating hypertensive disorders of pregnancy. An Indian rural experience. J Obstet Gynaecol 2006; 26: 531-3. [CrossRef]

10. Wang Y, Wang J, Ye R, Zhao Y. Investigation of diagnosis and treatment of hemolysis-elevated liver enzymes-low platelet counts (HELLP) syndrome: clinical analysis of 59 cases. Chin Med J (Engl) 2010; 123: 1273-7.

11. Cavkaytar S, Ugurlu EN, Karaer A, Tapisiz OL, Danisman N. Are clinical symptoms more predictive than laboratory parameters for adverse maternal outcome in HELLP syndrome? Acta Obstet Gynecol Scand 2007; 86: 648-51. [CrossRef]

12. Liu CM, Chang SD, Cheng PJ, Chao AS. Comparisons of maternal and perinatal outcomes in Taiwanese women with complete and partial HELLP syndrome and women with severe pre-eclampsia without HELLP. J Obstet Gynaecol Res 2006; 32: 550-8. [CrossRef]

13. Ertan AK, Wagner S, Hendrik HJ, Tanriverdi HA, Schmidt W. Clinical and biophysical aspects of HELLP syndrome. J Perinat Med 2002; 30: 483-9. [CrossRef]

14. Imir GA, Ozdemir Kol I, Kaygusuz K, Cetin A, Cetin M, Guvenal T, et al. Perinatal outcomes in HELLP syndrome. J Turkish-German Gynecol Assoc 2008; 9: 89-93.

15. Mecacci F, Carignani L, Cioni R, Parretti E, Mignisa M, Piccioli A, et al. Time course of recovery and complications of HELLP syndrome with two different treatment: Heparin or dexametasone. Throm Res 2001; 102: 99-105. [CrossRef] 